\title{
Theoretical and Experimental Vibrational Characterization of Biologically Active Nd(III) Complex
}

\author{
Irena Kostova ${ }^{1}$, Jan Mojžiš ${ }^{2}$ (D) and Vasile Chiş ${ }^{3, *(D)}$ \\ 1 Department of Chemistry, Faculty of Pharmacy, Medical University, 2 Dunav St., 1000 Sofia, Bulgaria; \\ i.kostova@pharmfac.mu-sofia.bg \\ 2 Department of Pharmacology, Faculty of Medicine, P.J. Šafarik University, 04011 Košice, Slovakia; \\ jan.mojzis@upjs.sk \\ 3 Department of Biomolecular Physics, Faculty of Physics, Babeş-Bolyai University, \\ 400084 Cluj-Napoca, Romania \\ * Correspondence: vasile.chis@ubbcluj.ro; Tel.: +40-264-405300; Fax: +40-264-591906
}

Citation: Kostova, I.; Mojžiš, J.; Chiş, V. Theoretical and Experimental Vibrational Characterization of Biologically Active Nd(III) Complex. Molecules 2021, 26, 2726. https:// doi.org/10.3390/molecules26092726

Academic Editor: Maria

Paula Marques

Received: 6 April 2021

Accepted: 5 May 2021

Published: 6 May 2021

Publisher's Note: MDPI stays neutral with regard to jurisdictional claims in published maps and institutional affiliations.

Copyright: (c) 2021 by the authors. Licensee MDPI, Basel, Switzerland. This article is an open access article distributed under the terms and conditions of the Creative Commons Attribution (CC BY) license (https:// creativecommons.org/licenses/by/ $4.0 /)$.

\begin{abstract}
The neodymium(III) complex of orotic acid (HOA) was synthesized and its structure determined by means of analytical and spectral analyses. Detailed vibrational analysis of HOA, sodium salt of $\mathrm{HOA}$, and $\mathrm{Nd}(\mathrm{III})-\mathrm{OA}$ systems based on both the calculated and experimental spectra confirmed the suggested metal-ligand binding mode. Significant differences in the IR and Raman spectra of the complex were observed as compared to the spectra of the ligand. The calculated vibrational wavenumbers, including IR intensities and Raman scattering activities, for the ligand and its $\mathrm{Nd}(\mathrm{III})$ complex were in good agreement with the experimental data. The vibrational analysis performed for the studied species, orotic acid, sodium salt of orotic acid, and its $\mathrm{Nd}$ (III) complex helped to explain the vibrational behaviour of the ligand's vibrational modes, sensitive to interaction with $\mathrm{Nd}(\mathrm{III})$. In this paper we also report preliminary results about the cytotoxicity of the investigated compounds. The cytotoxic effects of the ligand and its $\mathrm{Nd}(\mathrm{III})$ complex were determined using the MTT method on different tumour cell lines. The screening performed revealed that the tested compounds exerted cytotoxic activity upon the evaluated cell lines.
\end{abstract}

Keywords: Nd(III) complex; orotic acid; IR; Raman; DFT; cytotoxicity

\section{Introduction}

Lanthanide complexes are of great interest because of their various potential applications. Due to the unique nature of lanthanide ions, such as their large radius and high coordination number, the assembly of lanthanide complexes possessing novel structures and special properties offers great challenges and opportunities in terms of controlling their shapes and dimensions. The selection of an appropriate organic ligand along with different synthetic methods is a key step in the construction of lanthanide complexes with the desired features. Ligands containing a combination of nitrogen and oxygen donor atoms demonstrate flexible coordination modes during the formation of coordination frameworks, which is why the studied lanthanide(III) complexes of biologically active derivatives of orotic acid deserve to be examined.

The coordination chemistry of orotic acid (2,6-dioxo-1,2,3,6-tetrahydropyrimidine4-carboxylic acid, vitamin $\mathrm{B}_{13}$, or $\mathrm{HOA}$ ) and its sodium salt (NaOA) (see Figure 1 ) has been an area of great interest [1-5], ranging from bioinorganic to pharmaceutical and materials chemistry.

Metal orotates are widely applied in medicine [6], with platinum, palladium, and nickel orotate complexes being screened as potential therapeutic agents for cancer [7]. More recent interest has focused on the proposed biological function of orotic acid and its corresponding anions in binding biogenic metal ions, which is held responsible for the successful application of orotate complexes in curing syndromes associated with a 
deficiency of a variety of metals-such as $\mathrm{Ca}, \mathrm{Mg}, \mathrm{Zn}$, or Fe-thus delivering these metals conveniently to patients [4-6]. However, previous studies on the coordination chemistry of orotic acid mainly focused on transition metals or alkali metals, while the lanthanides have been neglected.
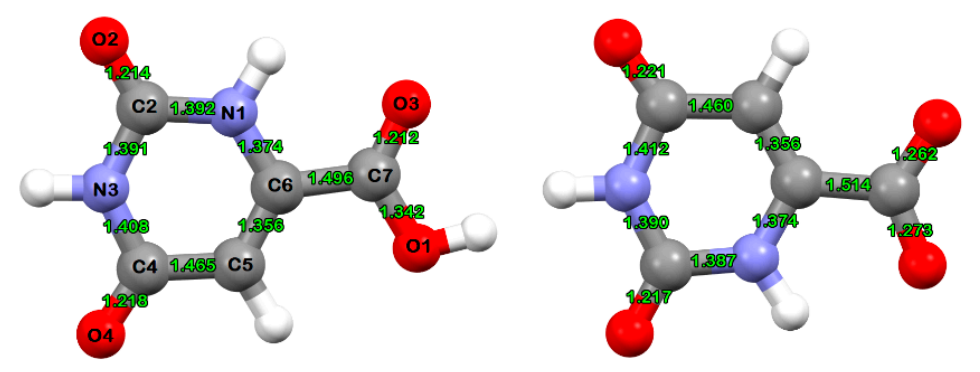

Figure 1. B3LYP/cc-pVDZ(SDD)-optimized molecular structures of the orotic acid ligand (left) and the orotic acid anion (right).

Aside from the significance of orotic acid and its derivatives in biological systems, these compounds possess fascinating coordination behaviour with potential hydrogenbonding interactions, such as asymmetric geometry and multiple coordination sites. Orotic acid acts as a diacid in aqueous solution [8,9]. The multifunctionality of its anions offers interesting possibilities in crystal engineering as a versatile ligand for supramolecular assemblies. The coordinated orotate anions exhibit a ligand surface with double or triple hydrogen-bonding capabilities, depending on the metal coordination mode, and thus have the potential to adopt several modes of interligand hydrogen bonding to allow for the formation of extended, self-assembled structures. Orotic acid has demonstrated versatile coordination modes during the formation of coordination frameworks, which is why it was a challenge for us to obtain new lanthanide(III) coordination complexes with this ligand, especially in view of their application as anticancer agents. To the best of our knowledge, little is known about lanthanide(III) coordination compounds with orotic acid, and such complexes possessing cytotoxic activity has not been previously reported. We have recently synthesized lanthanide complexes with a number of biologically active ligands, and we reported their significantly high cytotoxic activity in different human tumour cell lines [10-18]. These promising results prompted us to search for new lanthanide complexes with orotic acid. Thus, the aim of this work was to synthesize and characterize a complex of neodymium(III) with orotic acid and, subsequently, to evaluate its cytotoxic activity.

The present work is a continuation of our earlier long experience with lanthanide complexes. In this paper we report a joint theoretical, analytical, and spectroscopic study on the new $\mathrm{Nd}(\mathrm{III})$ complex of orotic acid (HOA). The $\mathrm{Nd}$ (III)-OA binding mode was identified and characterized via elemental analysis, along with both IR and Raman spectroscopy, coupled with quantum chemical calculations based on density functional theory (DFT). The cytotoxic effects of the ligand and its $\mathrm{Nd}$ (III) complex were determined via the MTT method using different tumour cell lines. Recently we have reported thorough studies on the optimized geometries and vibrational characterization of different $\operatorname{Ln}(\mathrm{III})$ model systems (some of them similar to the investigated one) to suggest the metal-ligand binding mode by using high-level theoretical methods [10-19]. This detailed theoretical approach helped to predict correctly the metal coordination polyhedron of the studied complex. The recorded spectra of the $\mathrm{Ln}(\mathrm{III})$ complexes are very similar, and this finding is indicative of similar binding of the ligand and similar coordination polyhedrons of the complexes. The applied methodology proved to be reliable for the series of lanthanide complexes, and the results are in good agreement with those existing in the literature. Since the crystal structure data are not available, theoretical approaches for determination of the geometrical parameters, vibrational frequencies, hydrogen bond strengths, and the binding mode for 
the model $\mathrm{Ln}(\mathrm{III})-\mathrm{OA}$ at a high level of theory are very helpful for extracting reliable structural information.

\section{Results and Discussion}

\subsection{Chemistry}

The new complex was characterized via elemental analysis. The content of the metal ion was determined after mineralization. The water content of the complex was determined via Karl Fischer titration and thermogravimetric analysis. IR and Raman spectra confirmed the nature of the complex.

The obtained elemental analysis data of the new neodymium(III) complex served as the basis for the determination of its empirical formula, and the results of the Karl Fischer titration are presented below.

Elemental analysis of the $\mathrm{Nd}(\mathrm{III})$ complex of orotic acid: (\% calculated/found): $\mathrm{Nd}(\mathrm{OA})_{2}(\mathrm{OH}) .3 \mathrm{H}_{2} \mathrm{O}: \mathrm{C}: 22.86 / 23.05 ; \mathrm{H}: 2.48 / 2.69 ; \mathrm{N}: 10.66 / 10.37 ; \mathrm{H}_{2} \mathrm{O}: 10.28 / 9.88 ; \mathrm{Nd}$ : 27.43/27.15, where $\mathrm{HOA}=\mathrm{C}_{5} \mathrm{~N}_{2} \mathrm{O}_{4} \mathrm{H}_{4}$ and $\mathrm{OA}^{-}=\mathrm{C}_{5} \mathrm{~N}_{2} \mathrm{O}_{4} \mathrm{H}_{3}{ }^{-}$.

The mode of bonding of the ligand to the $\mathrm{Nd}(\mathrm{III})$ ions was elucidated by recording the IR and Raman spectra of the complex and comparing them with those of the free ligand and with the theoretical predictions. The vibrational band assignments for the ligand [19] and the $\mathrm{Nd}(\mathrm{III})$ complex were made on the basis of DFT calculations by comparison with the results reported previously in the literature [20-26].

\subsection{Geometry Optimization}

Because no crystal structure data were available for the $\mathrm{Nd}(\mathrm{III})$ complex of orotic acid, its structure was optimized at the B3LYP/cc-pVDZ(SDD) level of theory and compared with the literature data for compounds containing identical or similar functional groups [27].

The determination of the binding mode on the basis of physicochemical and spectroscopic methods, when crystal and molecular structure data are not available, is not a trivial task. Unfortunately, due to poor solubility we did not succeed in obtaining a single crystal suitable for X-ray diffraction analysis and, hence, the complex crystal and molecular structures are not known. Therefore, we undertook a combined theoretical and experimental study aiming to determine the binding mode of the ligand and the molecular geometry of its complex.

Different binding modes have been tested for the $\mathrm{Nd}(\mathrm{III})$ complex, and the one reported here reproduced the best available experimental vibrational data. For all other presumed binding modes it was either not possible to achieve the geometric convergence (NdIII)-2OA- $2 \mathrm{H}_{2} \mathrm{O}$, neutral, singlet) or else the calculated vibrational spectra predicted one or more imaginary frequencies $\left(\mathrm{Nd}(\mathrm{III})-2 \mathrm{OA}-\mathrm{H}_{2} \mathrm{O}-\mathrm{OH}\right.$ complex, neutral, doublet) or provided very bad agreement with the experimental data $\left(\mathrm{Nd}(\mathrm{III})-2 \mathrm{OA}-\mathrm{H}_{2} \mathrm{O}-\mathrm{OH}\right.$ complex, mono-cation, singlet).

Moreover, the calculated vibrational spectra for the proposed complex are in line with the data reported for a similar binding mode of a $\mathrm{Co}$ (II)-orotate complex reported by Brockner et al. (see Table 4 in Reference [28]).

The calculated $\mathrm{Nd}-\mathrm{O}$ distances of the new $\mathrm{Nd}$ (III) complex of orotic acid are listed in Table 1. The $\mathrm{Nd}(\mathrm{III})$ ion is at least three-coordinate, with bonds to the oxygen atoms from the carboxylates of the orotate ligands and to the oxygen atom from the hydroxyl anion. The complex is mononuclear, and each local coordination unit around the metal ion contains two orotate ligands and one $\mathrm{OH}^{-}$ion. The calculated partial atomic polar tensor (APT) charges on the $\mathrm{Nd}$ and $\mathrm{O}$ atoms are also included in Table 1. 
Table 1. Calculated Nd-O distances and APT partial atomic charges of the $\mathrm{Nd}(\mathrm{III})$ complex of orotic acid at the B3LYP/cc-pVDZ(SDD) level of theory.

\begin{tabular}{ll}
\hline Nd-O Distances & Calculated Value (̊) \\
\hline $\mathrm{Nd}-\mathrm{O} 1$ & 2.155 \\
$\mathrm{Nd}-\mathrm{O} 1^{\prime}$ & 2.381 \\
$\mathrm{Nd}-\mathrm{O} 3^{\prime}$ & 2.441 \\
$\mathrm{Nd}-\mathrm{O} 5$ & 2.061 \\
$\mathrm{APT}$ partial atomic charges & Calculated value $(\mathrm{e})$ \\
$\mathrm{Nd}$ & +2.812 \\
$\mathrm{O} 1$ & -1.558 \\
$\mathrm{O}^{\prime}$ & -1.109 \\
$\mathrm{O}^{\prime}$ & -1.101 \\
$\mathrm{O} 5$ & -1.186 \\
\hline
\end{tabular}

\subsection{Vibrational Spectroscopy}

In Table 2 are reported selected calculated and experimental IR and Raman data, together with their tentative assignments. The last column in Table 1 contains the motions that contribute the most to different normal modes of the $\mathrm{Nd}$ (III) complex, according to B3LYP/cc-pVDZ(SDD) theoretical data.

Table 2. Selected theoretical B3LYP-cc-pVDZ(SDD) and experimental IR and Raman wavenumbers ( $\left.\mathrm{cm}^{-1}\right)$ of the Nd(III) complex (NdOA), and their tentative assignment. Experimental data for orotic acid (HOA) and its anion $\left(\mathrm{OA}^{-}\right)$are included for comparative purposes.

\begin{tabular}{|c|c|c|c|c|c|c|c|c|}
\hline \multirow{2}{*}{$\begin{array}{l}\text { Mode } \\
\text { nr. }\end{array}$} & \multirow{2}{*}{$\begin{array}{c}\text { Scaled Wave } \\
\text { Numbers }\left(\mathrm{cm}^{-1}\right)\end{array}$} & \multicolumn{3}{|c|}{ Exp. Raman } & \multicolumn{3}{|c|}{ Exp. IR } & \multirow{2}{*}{ Assignments } \\
\hline & & HOA & OA- & NdOA & HOA & OA- & NdOA & \\
\hline 1 & 190 & - & - & - & - & - & - & $\delta(\mathrm{ONdO})$ \\
\hline 2 & 265 & - & - & - & - & - & - & $v(\mathrm{O} 1-\mathrm{Nd}), \delta(\mathrm{C} 6-\mathrm{C} 7-\mathrm{O} 1)$ \\
\hline 3 & 278 & - & - & - & - & - & - & $v\left(\mathrm{O}^{\prime}-\mathrm{Nd}\right), \delta\left(\mathrm{C}^{\prime}-\mathrm{C}^{\prime}-\mathrm{O} 3^{\prime}\right)$ \\
\hline 4 & 459 & - & - & - & - & 435 & 442 & $v\left(\mathrm{O} 1^{\prime}-\mathrm{Nd}\right), v\left(\mathrm{O} 3^{\prime}-\mathrm{Nd}\right), \delta\left(\mathrm{C}^{\prime}-\mathrm{C}^{\prime}-\mathrm{O} 1^{\prime}\right), \delta\left(\mathrm{C}^{\prime}-\mathrm{C}^{\prime}-\mathrm{O}^{\prime}\right)$ \\
\hline 5 & 466 & 460 & 459 & 461 & 451 & - & - & $\delta(\mathrm{C} 6-\mathrm{C} 7-\mathrm{O} 1), \delta(\mathrm{C} 7-\mathrm{O} 1-\mathrm{Nd}), \delta(\mathrm{N} 1-\mathrm{C} 2-\mathrm{O} 2)$ \\
\hline 6 & 514 & 513 & 514 & 510 & 507 & 509 & 517 & $\delta(\mathrm{O} 5-\mathrm{H} 6), \gamma(\mathrm{N} 1-\mathrm{C} 6)$ \\
\hline 7 & 535 & 546 & 551 & 539 & 555 & 555 & 548 & $\delta(\mathrm{C} 6-\mathrm{C} 5-\mathrm{C} 4), \delta(\mathrm{C} 5-\mathrm{C} 4-\mathrm{N} 3), \delta(\mathrm{N} 3-\mathrm{C} 4-\mathrm{O} 4), \delta(\mathrm{C} 2-\mathrm{N} 1-\mathrm{C} 6)$ \\
\hline 8 & 610 & 608 & 605 & 595 & 603 & 600 & 595 & $v(\mathrm{Nd}-\mathrm{O} 5)$ \\
\hline 9 & 657 & 655 & 642 & 645 & - & 639 & 643 & $\gamma(\mathrm{N} 1-\mathrm{H} 1), \gamma(\mathrm{N} 3-\mathrm{H} 3), \gamma(\mathrm{C} 5-\mathrm{H} 5)$ \\
\hline 10 & 765 & 753 & - & - & 758 & 758 & 757 & $\gamma\left(\mathrm{C} 2^{\prime} \mathrm{O}\right), \gamma\left(\mathrm{C} 2^{\prime} \mathrm{N}\right)$ \\
\hline 11 & 788 & - & 780 & 779 & 774 & 779 & 771 & $\delta\left(\mathrm{C} \mathrm{O}_{2}\right), v(\mathrm{NdO} 1)$ \\
\hline 12 & 798 & 793 & - & 794 & 785 & 796 & 799 & $\delta\left(C 7^{\prime} \mathrm{O}_{2}\right)$ \\
\hline 13 & 886 & 887 & 856 & 852 & 892 & 853 & 859 & $\gamma\left(\mathrm{C} 4^{\prime}-\mathrm{H}^{\prime}\right), \gamma\left(\mathrm{C} 4^{\prime}-\mathrm{C} 5^{\prime}\right), \gamma\left(\mathrm{C} 5^{\prime}-\mathrm{C} 6^{\prime}\right), \gamma\left(\mathrm{C} 6^{\prime}-\mathrm{N} 1^{\prime}\right)$ \\
\hline 14 & 931 & 932 & 934 & 933 & 930 & 929 & 933 & 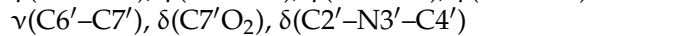 \\
\hline 15 & 1012 & 1011 & 1018 & 1006 & 1015 & 1018 & 1015 & $\delta\left(\mathrm{C} 2^{\prime}-\mathrm{N} 1^{\prime}-\mathrm{C} 6^{\prime}\right), \delta\left(N 1^{\prime}-\mathrm{C} 6^{\prime}-\mathrm{C} 5^{\prime}\right), \delta\left(C 4^{\prime}-\mathrm{C}^{\prime}-\mathrm{C} 6^{\prime}\right)$ \\
\hline 16 & 1032 & 1047 & 1048 & 1032 & 1042 & 1042 & 1036 & $\delta\left(\mathrm{C}^{\prime}-\mathrm{C} 6^{\prime}-\mathrm{N} 1^{\prime}\right), \delta\left(\mathrm{C}^{\prime}-\mathrm{N} 1^{\prime}-\mathrm{C} 2^{\prime}\right), v\left(\mathrm{C} 6^{\prime}-\mathrm{C} 7^{\prime}\right)$ \\
\hline 17 & 1085 & 1135 & 1117 & - & 1125 & - & 1121 & $\beta(\mathrm{C} 5-\mathrm{H} 5), \delta(\mathrm{C} 5 \mathrm{C} 6 \mathrm{~N} 1), v\left(\mathrm{Nd}-\mathrm{O} 1^{\prime}\right)$ \\
\hline 18 & 1215 & 1255 & 1239 & 1226 & 1241 & 1234 & 1232 & $v(\mathrm{C} 7-\mathrm{O} 1)$ \\
\hline 19 & 1292 & 1282 & 1294 & 1295 & 1284 & - & - & $\beta(\mathrm{N} 1-\mathrm{H} 1), \beta(\mathrm{C} 5-\mathrm{H} 5), \gamma(\mathrm{C} 6-\mathrm{C} 7)$ \\
\hline 20 & 1347 & 1326 & - & - & 1345 & 1322 & 1311 & $\delta(\mathrm{N} 3-\mathrm{H} 3)$ \\
\hline 21 & 1384 & - & 1386 & 1389 & - & 1386 & 1384 & $\delta(\mathrm{N} 3 \mathrm{C} 2 \mathrm{O} 2), v(\mathrm{C} 2 \mathrm{~N} 1), \delta(\mathrm{C} 2 \mathrm{~N} 1 \mathrm{H} 1)$ \\
\hline 22 & 1399 & 1414 & 1428 & 1410 & 1407 & 1426 & 1407 & $v\left(\mathrm{C} 6^{\prime}-\mathrm{C} 7^{\prime}\right), v_{\mathrm{s}}\left(\mathrm{C}^{\prime} \mathrm{O}_{2}\right)$ \\
\hline 23 & 1521 & 1522 & 1498 & - & 1525 & 1497 & - & $v_{a s}\left(C 7^{\prime} \mathrm{O}_{2}\right)$ \\
\hline 24 & 1626 & 1615 & - & 1615 & 1617 & 1620 & 1602 & $v(\mathrm{C} 5-\mathrm{C} 6)$ \\
\hline 25 & 1638 & 1657 & 1652 & 1667 & 1655 & 1654 & 1653 & $v\left(C 6^{\prime}-C 5^{\prime}\right)$ \\
\hline 26 & 1745 & - & 1684 & 1688 & 1684 & 1696 & 1684 & $v(\mathrm{C} 7 \mathrm{O} 3), v(\mathrm{C} 4 \mathrm{O} 4)$ \\
\hline 27 & 1753 & 1713 & 1710 & 1714 & 1712 & 1707 & 1728 & $v(\mathrm{C} 2 \mathrm{O} 2)$ \\
\hline 28 & 1783 & - & 1746 & 1744 & 1734 & 1741 & 1743 & $v\left(\mathrm{C} 2^{\prime} \mathrm{O} 2^{\prime}\right)$ \\
\hline 29 & 3164 & - & - & 3108 & - & 3116 & - & $v(\mathrm{C} 5-\mathrm{H} 5)$ \\
\hline 30 & 3386 & - & - & - & 3520 & 3214 & 3417 & $v(\mathrm{~N} 1-\mathrm{H} 1)$ \\
\hline 31 & 3682 & 3144 & - & - & 3232 & - & 3201 & $v(\mathrm{O} 5-\mathrm{H} 6)$ \\
\hline
\end{tabular}

The computed wavenumbers have been scaled by 0.971 [29]. To aid in mode assignment, we based this on the direct comparison between the experimental and calculated spectra, by considering both the frequency sequence and the intensity pattern. 
The vibrational IR and Raman spectra of HOA, sodium salt of orotic acid (NaOA), and $\mathrm{Nd}(\mathrm{III})-\mathrm{OA}$ are presented in Figures 2 and 3.

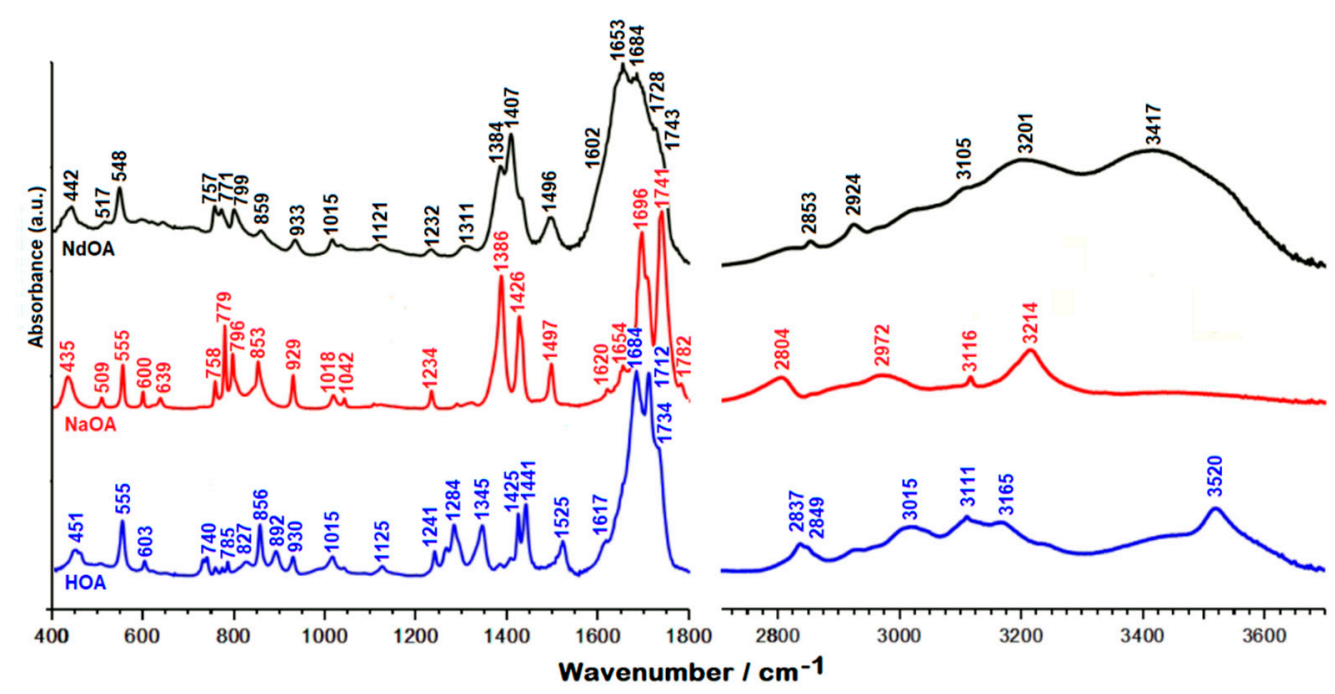

Figure 2. IR spectra of orotic acid (HOA), sodium salt of orotic acid (NaOA), and its $\mathrm{Nd}(\mathrm{III})$ complex (NdOA).

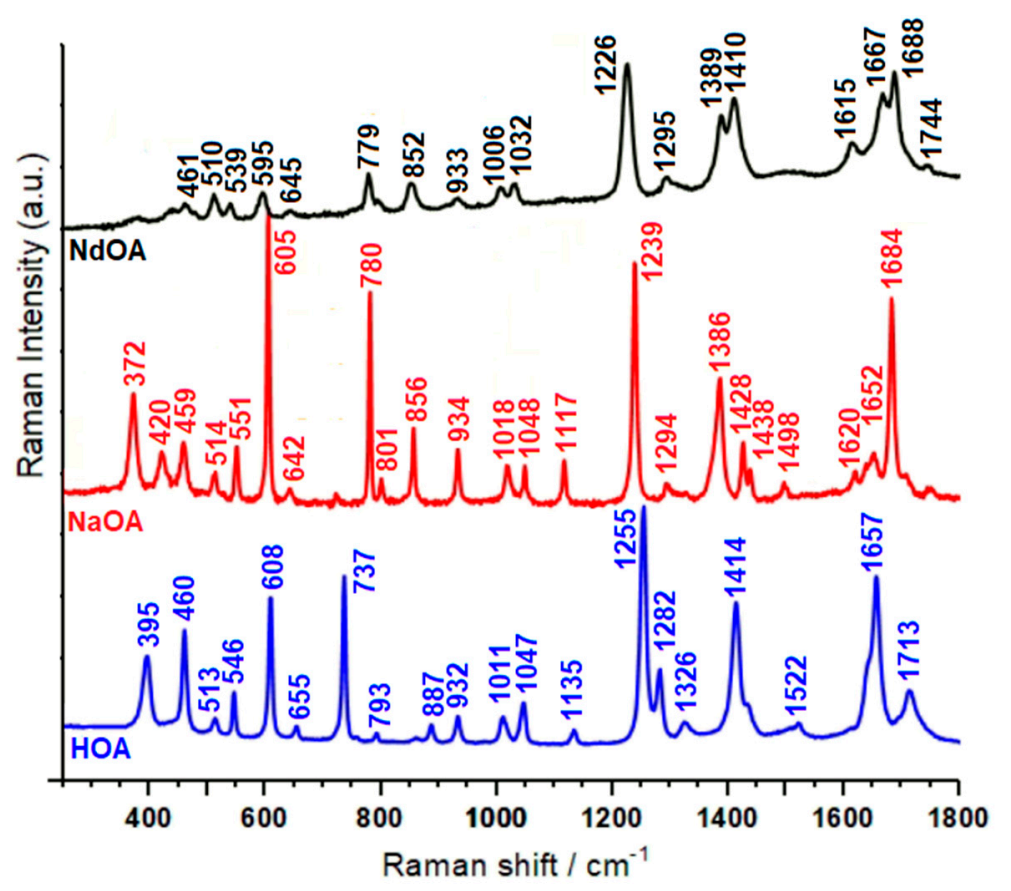

Figure 3. Raman spectra of the solid state of orotic acid (HOA), sodium salt of orotic acid (NaOA), and its $\mathrm{Nd}$ (III) complex. Excitation: $784.8 \mathrm{~nm}, 35 \mathrm{~mW}$.

In the $3600-2000 \mathrm{~cm}^{-1}$ spectral region from the IR spectrum, the $\mathrm{O}-\mathrm{H}$ and $\mathrm{N}-\mathrm{H}$ stretches give rise to medium IR bands (Figure 2). The assignment of the $\mathrm{O}-\mathrm{H}$ and $\mathrm{N}-\mathrm{H}$ bands is quite difficult because they appear to overlap in the same spectral region, and the involvement of these groups in hydrogen bonds affects their wavenumbers and produces a relevant band broadening [21,23-26]. In the IR spectra, the medium bands at $3520 \mathrm{~cm}^{-1}$ (orotic acid) and $3417 \mathrm{~cm}^{-1}(\mathrm{Nd}$ (III) complex of orotic acid) were assigned to the $\mathrm{N}-\mathrm{H}$ stretching modes, while the shoulder at $3232 \mathrm{~cm}^{-1}$ (orotic acid) and the medium band at $3201 \mathrm{~cm}^{-1}(\mathrm{Nd}$ (III) complex of orotic acid) were attributed to the $\mathrm{O}-\mathrm{H}$ stretching modes (Table 2). 
When the carbonyl group is hydrogen bonded but not dimerized, active IR and Raman bands are expected at 1730-1705 $\mathrm{cm}^{-1}$. In our IR spectra (Figure 2), one very strong band can be observed in this region (at $1712 \mathrm{~cm}^{-1}$ for orotic acid), which was assigned to the $\mathrm{C}=\mathrm{O}$ stretching modes. In the same region we observed one medium band at $1713 \mathrm{~cm}^{-1}$ in the Raman spectrum of the free ligand, and two shoulders at 1743 and $1728 \mathrm{~cm}^{-1}$ in the Raman spectrum of the complex (Figure 3) [27,30-33]. According to theoretical data shown in Table 2, these vibrations can safely be assigned to the $\mathrm{C}=\mathrm{O}$ stretching modes of carbonyl groups.

As shown in Figures 2 and 3, in the 1600-1700 $\mathrm{cm}^{-1}$ region, both the IR and Raman spectra of the complex are changed drastically with respect to the free orotic acid. This change is to be expected assuming the coordination of the HOA to the $\mathrm{Nd}(\mathrm{III})$ ion through the $\mathrm{COO}^{-}$group of HOA. The very strong bands observed at 1684 and $1688 \mathrm{~cm}^{-1}$ in the IR and Raman spectra of the $\mathrm{Nd}(\mathrm{III})$ complex were assigned to the asymmetric $\mathrm{C}=\mathrm{O}$ stretching mode. In the case of unidentate ligands, the symmetric stretch of the COO group is expected to give a band in the $1420-1260 \mathrm{~cm}^{-1}$ region [34]. Indeed, for the $\mathrm{Nd}(\mathrm{III})$ complex we observe this vibration at 1407 and $1411 \mathrm{~cm}^{-1}$ in the IR and Raman spectra, respectively. Computational data support this assignment, with the vibration being predicted at $1399 \mathrm{~cm}^{-1}$, coupled to the $C-C$ stretching modes. These findings are in agreement with the data reported by Dobblaere et al. for glycolato(-peroxo)-Ti(IV) complexes [35]. Moreover, the difference between the wavenumbers corresponding to the asymmetric and symmetric COO stretching modes is $277 \mathrm{~cm}^{-1}$, in perfect agreement with previously reported data for complexes with one monodentate and one bidentate ligand.

Another band indicative of monodentate and bidentate coordination of $\mathrm{Nd}(\mathrm{III})$ ions is the very strong band corresponding to the C7-O1 stretch, which is observed in the Raman spectrum at $1226 \mathrm{~cm}^{-1}$ and as a weak band at $1232 \mathrm{~cm}^{-1}$ in the IR spectrum. As seen in Table 2, this is significantly red-shifted with respect to the case of free OAH [19].

The $\mathrm{C}=\mathrm{C}$ double bond stretching modes in the two heterocycles give rise to mediumstrong absorptions observed for the $\mathrm{Nd}(\mathrm{III})$ complex in the Raman spectrum at 1667 and $1615 \mathrm{~cm}^{-1}$, and in the IR spectrum at 1653 and $1602 \mathrm{~cm}^{-1}$. The positions of these bands remain very close to those observed for the free ligand.

A characteristic band for the complex but absent for the free ligand is that seen in the IR spectrum at $1496 \mathrm{~cm}^{-1}$, also observed as a very weak and broad band in the Raman spectrum at $1502 \mathrm{~cm}^{-1}$. According to quantum chemical calculations this is mainly due to the $\mathrm{N} 1 \mathrm{H}$ bending, coupled to C6N1 stretching.

The $\mathrm{C} 5-\mathrm{H} 5, \mathrm{~N} 1-\mathrm{H} 1$, and $\mathrm{C}-\mathrm{O}-\mathrm{H}$ bending modes are present in the IR spectrum at $1284 \mathrm{~cm}^{-1}$ for the free ligand, while in the Raman spectrum they are detected at $1282 \mathrm{~cm}^{-1}$ and $1295 \mathrm{~cm}^{-1}$, respectively. The weak band at $1266 \mathrm{~cm}^{-1}$, which can be observed only in the IR spectrum of the orotic acid, can be due to the $\mathrm{C}=\mathrm{O}$ bending mode and to the symmetrical stretching mode of N1-C2-N3. According to theoretical data, the bands around $1015 \mathrm{~cm}^{-1}$, weak in IR and medium in Raman spectra, are due to in-plane deformations of uracilate rings, whereas bands around $930 \mathrm{~cm}^{-1}$, almost weak in IR and medium in Raman spectra, were attributed to the symmetrical C(ring)-C(carboxyl) bridge bond stretching mode.

The uracilate ring bending vibration and the skeletal deformation bands of the free orotic acid, mainly in the $900-300 \mathrm{~cm}^{-1}$ wavenumber region, show considerable changes in complex formation. These changes may be attributed to distortion of the uracilate rings upon coordination.

The medium band at $779 \mathrm{~cm}^{-1}$ seen in the Raman spectrum of the complex is due to the bending of the carboxylate group coupled with the $\mathrm{Nd}-\mathrm{O}$ stretching. Moreover, the $\mathrm{Nd}-\mathrm{O}$ stretching contributes greatly to the medium band observed in the Raman spectrum of the complex at $595 \mathrm{~cm}^{-1}$.

The new bands at $442 \mathrm{~cm}^{-1}$ in the IR spectrum and at $440 \mathrm{~cm}^{-1}$ (very weak) in the Raman spectrum, which appear only for the $\mathrm{Nd}$ (III) complex, are due to the neodymiumoxygen stretching $[21,22,26]$, being predicted at $459 \mathrm{~cm}^{-1}$ by DFT calculations. In the 
low wavenumbers region of the Raman spectrum of orotic acid (Figure 3), the medium strong band at $395 \mathrm{~cm}^{-1}$ is shifted to the shorter wavenumbers in the Raman spectrum of the $\mathrm{Nd}(\mathrm{III})$ complex $\left(373 \mathrm{~cm}^{-1}\right)$, and becomes weaker. As seen in Table 2, this band is due to $\delta(\mathrm{OCN})$ deformations coupled with $\mathrm{Nd}-\mathrm{O}$ stretching, according to the literature data [36-40]. The metal affects the carboxylate anion as well as the ring structure. The ionic potential [41] of the metal is the most important parameter responsible for the influence of the metal on the rest of the molecule [42-44]. The carboxylic acids interact with the metals as symmetric [45,46] bidentate carboxylate anions, and both oxygen atoms of the carboxylate are symmetrically bonded to the metal [47]. In this sense, we can observe in the Raman spectrum of the $\mathrm{Nd}$ (III) complex a medium weak peak at $211 \mathrm{~cm}^{-1}$, which, according to the computational data, is due to the O-Nd-O vibration modes (Table 2) [40,48-50].

In conclusion, the complex described above demonstrates once more the versatility of the orotate ligand, which adopts different coordination modes. The different charge and coordination modes of the ligand have a major effect on the supramolecular structures adopted by the complex. From previous results and this work, it is clear that the nature of orotic acid makes its various anionic forms versatile ligands for use with a variety of metals and for a variety of objectives/advantages, including variable coordination modes, high-nuclearity aggregate formation, and/or linking of aggregates into polymeric arrays. Thus, orotic acid has great potential as a generally useful new polyfunctional ligand in metal chemistry, and will prove attractive to a variety of coordination chemists.

On the basis of the detailed vibrational analysis, the most probable structure of the obtained $\mathrm{Nd}$ (III) complex was predicted, and is shown in Figure 4.

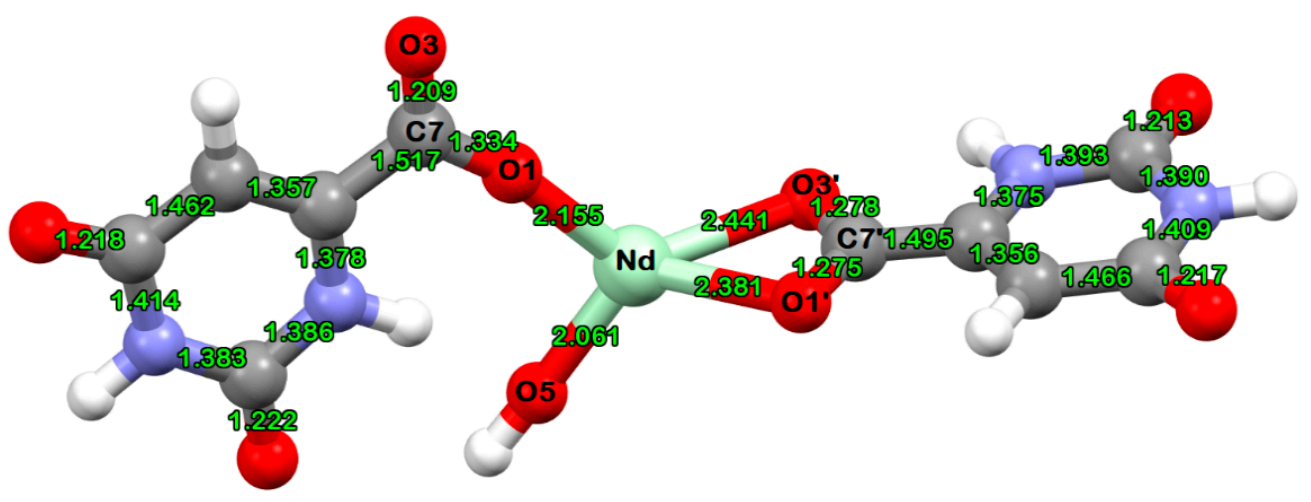

Figure 4. B3LYP/cc-pVDZ(SDD)-optimized molecular structure of the $\mathrm{Nd}(\mathrm{III})$ complex of orotic acid.

\subsection{Pharmacology}

The results of the preliminary cytotoxic screening of orotic acid, sodium salt of orotic acid, and the $\mathrm{Nd}(\mathrm{III})$ complex are presented in Table 3. The investigated compounds were tested for cytotoxic activity on the Jurkat (acute T-lymphoblastic leukemia, bcl-2 overexpressed), CCRF-CEM (acute T-lymphoblastic leukemia), HeLa (human cervical adenocarcinoma), A-549 (lung carcinoma), MCF-7 (mammary gland adenocarcinoma, oestrogen receptor expressed), and MDA-MB-231 (human breast adenocarcinoma, oestrogen receptornegative) cell lines. The results obtained indicate that the tested compounds exerted cytotoxic activity upon the evaluated cell lines.

These results confirmed our previous observations on the antioxidant activity and cytotoxicity of lanthanide(III) complexes with other biologically active ligands, such as 5-aminoorotic acid [51-53]. In the literature little was known about Ln(III) coordination compounds with orotic and 5-aminoorotic acid, and such complexes possessing antioxidant and anticancer activity had not been previously reported. The present work can be regarded as a continuation of our efforts in the bioinorganic chemistry of lanthanide(III) complexes with a number of biologically active ligands. 
Table 3. Cytotoxicity of the studied compounds at a concentration of $10^{-4} \mathrm{~mol} \cdot \mathrm{L}^{-1}$ (percentage of living cells compared to solvent control $(100 \%))$.

\begin{tabular}{ccccccc}
\hline \multirow{2}{*}{ Compound } & \multicolumn{7}{c}{ Cancer Cell Lines } \\
\cline { 2 - 7 } & Jurkat & CCRF-CEM & HeLa & A-549 & MCF & MDA \\
\hline HOA & 63.3 & 61.2 & 84.7 & 96.9 & 93.9 & 93.76 \\
NaOA & 58.6 & 64.8 & 78.6 & 90.6 & 100.0 & 93.7 \\
NdOA & 67.3 & 59.8 & 69.4 & 91.8 & 100 & 83.1 \\
\hline
\end{tabular}

Abbreviation: Jurkat cells (acute T-lymphoblastic leukemia, bcl-2 overexpressed); CCRF-CEM (acute Tlymphoblastic leukemia); HeLa (human cervical adenocarcinoma); A-549 (lung carcinoma); MCF-7 (mammary gland adenocarcinoma, oestrogen receptor expressed); and MDA-MB-231 (human breast adenocarcinoma, oestrogen receptor-negative).

\section{Materials and Methods}

\subsection{Synthesis of the Coordination Complex}

The compounds used for preparing the solutions were Merck products, pro analysis grade, $\mathrm{Nd}\left(\mathrm{NO}_{3}\right)_{3} \cdot 6 \mathrm{H}_{2} \mathrm{O}$. The sodium salt of orotic acid was used for the preparation of the metal complex as a ligand.

The complex was synthesized via the reaction of neodymium(III) nitrate and the sodium salt of orotic acid in aqueous solution, in amounts equal to a metal/ligand molar ratio of 1:2. The formation of the complex may be represented by the following equations:

$$
\begin{gathered}
\mathrm{NaOA}+\mathrm{H}_{2} \mathrm{O} \leftrightarrow \mathrm{Na}^{+}+\mathrm{OH}^{-}+\mathrm{HOA} \\
{\left[\mathrm{Nd}\left(\mathrm{H}_{2} \mathrm{O}\right)_{\mathrm{n}}\right]^{3+}+\mathrm{H}_{2} \mathrm{O} \leftrightarrow\left[\mathrm{Nd}(\mathrm{OH})\left(\mathrm{H}_{2} \mathrm{O}\right)_{\mathrm{n}-1}\right]^{2+}+\mathrm{H}_{3} \mathrm{O}^{+}} \\
{\left[\mathrm{Nd}(\mathrm{OH})\left(\mathrm{H}_{2} \mathrm{O}\right)_{\mathrm{n}-1}\right]^{2+}+2 \mathrm{OA}^{-} \rightarrow \mathrm{Nd}\left(\mathrm{OA}^{-}\right)_{2}(\mathrm{OH})\left(\mathrm{H}_{2} \mathrm{O}\right)+(\mathrm{n}-3) \mathrm{H}_{2} \mathrm{O},}
\end{gathered}
$$

where $\mathrm{HOA}=\mathrm{C}_{5} \mathrm{~N}_{2} \mathrm{O}_{4} \mathrm{H}_{4}$ and $\mathrm{OA}^{-}=\mathrm{C}_{5} \mathrm{~N}_{2} \mathrm{O}_{4} \mathrm{H}_{3}{ }^{-}$.

The complex was prepared by adding an aqueous solution of neodymium(III) salt to an aqueous solution of the sodium salt of orotic acid. The reaction mixture was stirred with an electromagnetic stirrer at $25^{\circ} \mathrm{C}$ for $1 \mathrm{~h}$. At the moment of mixing of the solutions, a precipitate was obtained and then filtered (the $\mathrm{pH}$ of the filtrate was 5.0), washed several times with water, and dried in a desiccator to a constant weight.

The complex was insoluble in water, methanol, and ethanol, and well soluble in DMSO.

\subsection{Methods}

The carbon, hydrogen, and nitrogen contents of the compound were determined via elemental analysis. The water content was determined using a Metrohm Herizall E55 Karl Fischer titrator, and via thermogravimetric analysis.

The solid-state infrared spectra of the ligand and its $\mathrm{Nd}(\mathrm{III})$ complex were recorded in $\mathrm{KBr}$ in the $4000-400 \mathrm{~cm}^{-1}$ frequency range using an FT-IR 113V Bruker spectrometer.

The Raman spectra of orotic acid and its Nd(III) complex were recorded using a Raman spectrometer LabRAM HR-800 (Horiba Jobin Yvon Gmbh, Bensheim, Germany using the $784.8 \mathrm{~nm}$ excitation line from a near-infrared diode laser. The LabRAM integrated system was coupled through an Olympus LMPlanFL $50 \times$ objective to the optical microscope. The spectra were collected through the backscattering geometry with a resolution of $2 \mathrm{~cm}^{-1}$. The detection of the Raman signals was carried out using a Peltier-cooled CCD camera. A laser power of $35 \mathrm{~mW}$ was used in our measurements.

\subsection{Computational Details}

The optimization and single-point calculations of the HOA, the OA anion, and the doublet state of the OA-Nd complex were performed using the Gaussian 09, revision A.02 software package [54], by using DFT approaches. For quantum chemical calculations we used the hybrid B3LYP exchange- correlation functional [55-58]. The cc-pVDZ basis 
set [59] was used for $\mathrm{H}, \mathrm{C}, \mathrm{N}, \mathrm{O}$, and $\mathrm{Na}$ atoms, while for the $\mathrm{Nd}$ atom we employed the SDD effective core potential and basis set. [60]

This level of theory has been selected based on the fact that the hybrid B3LYP-xc functional is recognized to provide good results for a variety of molecular properties, including geometries and vibrational spectra [61]. Given the relatively large size of the complex we had to find a compromise between the available computational resources and the accuracy of the computational data. For this reason we used the valence double-zeta basis set, coupled with the SDD effective core potential recommended for lanthanides [62].

Default criteria were used to define the convergence of both the electronic density and molecular geometries. Optimized molecular geometries were used to calculate the vibrational normal modes, within the harmonic approximation. Only real wavenumbers were obtained for all structures, confirming that they correspond to true minima on the potential energy surfaces.

\subsection{Tumour Cell Lines}

Jurkat (human T-cell acute lymphoblastic leukemia, bcl-2 overexpressed), HeLa (human cervical adenocarcinoma), MCF-7 (human breast adenocarcinoma, oestrogen receptorpositive), MDA-MB-231 (human breast adenocarcinoma, oestrogen receptor-negative), and A-549 (human lung adenocarcinoma) cell lines were kindly provided by Dr. M. Hajdúch (Olomouc, Czech Republic). The CCRF-CEM cell line (human T-cell acute lymphoblastic leukemia) was obtained from the German Collection of Microorganisms and Cell Cultures (Braunschweig, Germany).

The cells were routinely maintained in a RPMI 1640 medium with L-Glutamine and HEPES (Jurkat, HeLa and CCR-CEM), or in Dulbecco's modified Eagle's medium with Glutamax-I (MCF-7, MDA-MB-231, and A-549), supplemented with 10\% foetal calf serum, penicillin $\left(100 \mathrm{IU} \times \mathrm{mL}^{-1}\right)$, and streptomycin $\left(100 \mu \mathrm{g} \times \mathrm{mL}^{-1}\right)$ (all from Invitrogen, Waltham, MA, USA), in humidified air with $5 \% \mathrm{CO}_{2}$ at $37^{\circ} \mathrm{C}$. Before each cytotoxicity assay, cell viability was determined using the trypan blue exclusion method, and found to be greater than $95 \%$.

\subsection{Cytotoxicity Assay}

The cytotoxic effects of orotic acid, sodium salt of orotic acid, and the $\mathrm{Nd}(\mathrm{III})$ complex were determined using a colorimetric microculture assay with the MTT end-point [63]. Briefly, $3 \times 10^{3}$ (A-549, MCF-7, MDA-MB-231), $5 \times 10^{3}$ (HeLa), or $1 \times 10^{4}$ (Jurkat and CEM) cells were plated per well in 96-well polystyrene microplates (Sarstedt, Germany) in the culture medium containing the tested chemicals at final concentrations of $10^{-4}-10^{-9}$ $\mathrm{mol} \cdot \mathrm{L}^{-1}$. After $72 \mathrm{~h}$ of incubation, $10 \mu \mathrm{L}$ of MTT $\left(5 \mathrm{mg} \times \mathrm{mL}^{-1}\right.$ ) (Sigma, Darmstadt, Germany) were added to each well. After an additional $4 \mathrm{~h}$, during which insoluble formazan was produced, $100 \mu \mathrm{L}$ of $10 \%$ sodium dodecyl sulphate were added to each well, and another $12 \mathrm{~h}$ were allowed for the dissolution of the formazan. Absorbance was measured at $540 \mathrm{~nm}$ using an automated MRX microplate reader (Dynatech Laboratories, Chichester, UK). The blank-corrected absorbance of the control wells was taken as $100 \%$, and the results were expressed as a percentage of the control. All experiments were performed in triplicate.

\section{Conclusions}

The complex of neodymium(III) with orotic acid has been synthesized and characterized via elemental and vibrational (IR, Raman) analyses. The vibrational analysis performed for the studied species helped to explain the vibrational behaviour of the ligand vibrational modes, sensitive to interaction with $\mathrm{Nd}(\mathrm{III})$. The most probable metal-ligand binding mode in the $\mathrm{Nd}(\mathrm{III})$ complex of orotic acid was elucidated. It is suggested that orotic acid binds through the oxygen atoms of the carboxylic groups from both the ligands, and from one $\mathrm{OH}^{-}$ion. One of the two OA anions is monodentate, while the second one is in bidentate form, bound to the $\mathrm{Nd}(\mathrm{III})$ ion through the carboxylic oxygens. 
The results from the preliminary cytotoxic screening of orotic acid, sodium salt of orotic acid, and the $\mathrm{Nd}$ (III) complex demonstrate the anti-proliferative potential of the $\mathrm{Nd}(\mathrm{III})$ complex, which is in line with our preceding papers concerning the activity of lanthanide coordination compounds with diverse biologically active ligands. The complex formation proved to be beneficial for the efficacy of the $\mathrm{Nd}(\mathrm{III})$ complex, as the complex exerted efficacy vs. the corresponding ligands on all of the cell lines. Thus, this matter necessitates further, more detailed pharmacological evaluation. Additionally, the toxicology of the investigated compounds is of great interest with respect to their further pharmacological properties, and will be the subject of coming investigations.

Author Contributions: Conceptualization, I.K., J.M., and V.C.; methodology, I.K., J.M., and V.C.; investigation, I.K., J.M., and V.C.; writing—original draft preparation, I.K. and V.C.; writing-review and editing, I.K. and V.C.; supervision, I.K.; funding acquisition, I.K. and V.C. All authors have read and agreed to the published version of the manuscript.

Funding: V.C. highly acknowledges financial support from the CNCS/CCCDI UEFISCDI, project number PN-III-P2-2.1-PED-2016-0983, and the project MADECIP (POSCEE COD SMIS CSNR 48801/1862).

Institutional Review Board Statement: Not applicable.

Informed Consent Statement: Not applicable.

Conflicts of Interest: The authors declare no conflict of interest. The funders had no role in the design of the study, in the collection, analyses, or interpretation of data, in the writing of the manuscript, or in the decision to publish the results.

Sample Availability: A sample of the synthesized complex is available from the authors upon request.

\section{References}

1. Ruf, M.; Weiss, K.; Vahrenkamp, H. Pyrazolylborate-Zinc complexes of RNA precursors and analogues thereof. Inorg. Chem. 1997, 36, 2130-2137. [CrossRef] [PubMed]

2. Mutikainen, I.; Hämäläinen, R.; Klinga, K.; Orama, O.; Turpeinen, U. Triclinic form of tetraaqua(orotato-N,O)magnesium(II) hydrate at 153 K. Acta Crystallogr. C 1996, 52, 2480-2482. [CrossRef]

3. Hartmann, U.; Gregorzik, R.; Vahrenkamp, H. Functional zinc complexes of tris(imidazolylmethyl)amine Ligands. Chem. Ber. 1994, 127, 2123-2127. [CrossRef]

4. Kumberger, O.; Riede, J.; Schmidbaur, H. Preparation and crystal structure of zinc bis[orotate(1-)] octahydrate. Z. Naturforsch. Teil B 1993, 48, 961-964. [CrossRef]

5. Kumberger, O.; Riede, J.; Schmidbaur, H. Orotate complexes, II1) Preparation and crystal structures of calcium and zinc orotate(2-) hydrates. Chem. Ber. 1991, 124, 2739-2742. [CrossRef]

6. Schmidbaur, H.; Classen, H.-G.; Helbig, J. Aspartic and glutamic acid as ligands to alkali and alkaline-earth metals: Structural chemistry as related to magnesium therapy. Angew. Chem. Int. Ed. Engl. 1990, 29, 1090-1103. [CrossRef]

7. Matsumoto, K. Antitumor activities of platinum blues containing $\alpha$-pyrrolidone, 3-3-dimethylglutarimide, orotic acid, succinamic acid and oxamic acid. Inorg. Chim. Acta 1988, 151, 9-10. [CrossRef]

8. Mentzafos, D.; Katzaros, N.; Terzis, A. Synthesis and structure of bis(orotato)dioxouranium(VI) pentahydrate. Acta Crystallogr. C. 1987, 43, 1905-1908. [CrossRef]

9. Bach, I.; Kumberger, O.; Schmidbaur, H. Orotate complexes. Synthesis and crystal structure of lithium orotate(-I) monohydrate and magnesium bis[ orotate(-I)] octahydrate. Chem. Ber. 1990, 123, 2267-2271. [CrossRef]

10. Kostova, I.; Manolov, I.; Nicolova, I.; Konstantinov, S.; Karaivanova, M. New lanthanide complexes of 4-methyl-7hydroxycoumarin and their pharmacological activity. Eur. J. Med. Chem. 2001, 36, 339-347. [CrossRef]

11. Kostova, I.; Trendafilova, N.; Momekov, G. Theoretical and spectroscopic evidence for coordination ability of 3, 3'-benzylidenedi4-hydroxycoumarin. New neodymium (III) complex and its cytotoxic effect. J. Inorg. Biochem. 2005, 99, 477-487. [CrossRef]

12. Kostova, I.; Peica, N.; Kiefer, W. Theoretical and spectroscopic studies of lanthanum (III) complex of 5-aminoorotic acid. Chem. Phys. 2006, 327, 494-505. [CrossRef]

13. Kostova, I.; Trendafilova, N.; Georgieva, I. Spectroscopic and theoretical studies of a New Cerium (III) Complex with 3,3'-(orthoPyridinomethylene)di-[4-hydroxycoumarin]. Spectrosc. Lett. 2007, 40, 65-81. [CrossRef]

14. Kostova, I.; Trendafilova, N.; Mihailov, T. Theoretical and spectroscopic studies of pyridyl substituted bis-coumarins and their new neodymium (III) complexes. Chem. Phys. 2005, 314, 73-84. [CrossRef]

15. Kostova, I.; Manolov, I.; Momekov, G.; Tzanova, T.; Konstantinov, S.; Karaivanova, M. Cytotoxic activity of new cerium (III) complexes of bis-coumarins. Eur. J. Med. Chem. 2005, 40, 1246-1254. [CrossRef]

16. Kostova, I.; Peica, N.; Kiefer, W. Theoretical and spectroscopic studies of 5-aminoorotic acid and its new lanthanide(III) complexes. J. Raman Spectrosc. 2008, 38, 205-216. [CrossRef] 
17. Kostova, I.; Valcheva-Traykova, M. New samarium(III) complex of 5-aminoorotic acid with antioxidant activity. Appl. Organomet. Chem. 2015, 29, 815-824. [CrossRef]

18. Kostova, I.; Valcheva-Traykova, M. Synthesis, characterization, and antioxidant activity of a new Gd(III) complex. J. Coord. Chem. 2015, 68, 4082-4101. [CrossRef]

19. Kostova, I.; Peica, N.; Kiefer, W. Theoretical and spectroscopic studies of new lanthanum(III) complex of orotic acid. Vibr. Spectrosc. 2007, 44, 209-219. [CrossRef]

20. Hernanz, A.; Billes, F.; Bratu, I.; Navarro, R. Vibrational analysis and spectra of orotic acid. Biopolymers 2000, 57, 187-198. [CrossRef]

21. Wysokiński, R.; Morzyk-Ociepa, B.; Głowiak, T.; Michalska, D. Revised molecular structure and vibrational spectra of tetraaqua(orotato)nickel(II) monohydrate: Band assignment based on density functional calculations. J. Mol. Struct. (Theochem) 2002, 606, 241-251. [CrossRef]

22. Baran, E.J.; Mercader, R.C.; Hueso-Ureña, F.; Moreno-Carretero, M.N.; Quiros-Olozabal, M.; Salas-Peregrin, J.M. Crystal structure, raman and ${ }^{57} \mathrm{Fe}$ Mössbauer spectra of the FeII complex of iso-orotic acid. Polyhedron 1996, 15, 1717-1721. [CrossRef]

23. Batt, R.D.; Martin, J.K.; Ploeser, J.M.; Murray, J. Chemistry of the Dihydropyrimidines. Ultraviolet Spectra and Alkaline Decomposition. J. Am. Chem. Soc. 1954, 76, 3663-3665. [CrossRef]

24. Icbudak, H.; Olmez, H.; Yesilel, O.Z.; Arslan, F.; Naumov, P.; Jovanovski, G.; Ibrahim, A.R.; Usman, A.; Fun, H.K.; Chantrapromma, S.; et al. Syntheses, characterization and crystal structures of novel amine adducts of metal saccharinates, orotates and salicylates. J. Mol. Struct. 2003, 657, 255-270. [CrossRef]

25. Papaefstathiou, G.S.; Manessi, S.; Raptopoulou, C.P.; Behrman, E.J.; Zafiropoulos, T.F. The first metal complex of 5-hydroxyorotic acid: Dimethylammonium bis(N,N-dimethylformamide) bis(5-hydroxyorotato(-2))gallate(III). Inorg. Chem. Comm. 2004, 7, 69-72. [CrossRef]

26. Lencioni, S.; Pellerito, A.; Fiore, T.; Giuliani, A.M.; Pellerito, L.; Cambria, M.T.; Mansueto, C. Organometallic complexes with biological molecules. X: Dialkyltin(IV) and trialkyltin(IV) orotates: Spectroscopic and in vivo investigations. Appl. Organometal. Chem. 1999, 13, 145-157. [CrossRef]

27. Castaneda, J.; Denisov, G.S.; Kucherov, S.Y.; Schreiber, V.M.; Shurukhina, A.V. Infrared and ab initio studies of hydrogen bonding and proton transfer in the complexes formed by pyrazoles. J. Mol. Struct. 2003, 660, 25-40. [CrossRef]

28. Brockner, W.; Branscheid, R.; Gjikaj, M.; Adam, A. Synthesis, Crystal Structure and Vibrational Spectrum of Cobalt(II)orotate Trihydrate, [Co $\left(\mathrm{C}_{5} \mathrm{~N}_{2} \mathrm{O}_{4} \mathrm{H}_{2}\right) 3 \mathrm{H}_{2} \mathrm{O}$. Z. Naturforsch. B 2005, 60, 175-179. [CrossRef]

29. Sinha, P.; Boesch, S.E.; Gu, C.; Wheeler, R.A.; Wilson, A.K. Harmonic Vibrational Frequencies: Scaling Factors for HF, B3LYP, and MP2 Methods in Combination with Correlation Consistent Basis Sets. J. Phys. Chem. A 2004, 108, 9213-9217. [CrossRef]

30. Exner, K.; Fischer, G.; Bahr, N.; Beckmann, E.; Lugan, M.; Yang, F.; Rihs, G.; Keller, M.; Hunkler, D.; Knothe, L.; et al. Proximate, syn-Periplanar Bisdiazene Skeletons: Syntheses, Structures, Homoconjugate Reactivity and Photochemistry. Eur. J. Org. Chem. 2000, 5, 763-785. [CrossRef]

31. Gonzalez-Sanchez, F. Infra-red spectra of the benzene carboxylic acids. Spectrochim. Acta 1958, 12, 17-33. [CrossRef]

32. Hadzi, D.; Sheppard, N. The infra-red absorption bands associated with the $\mathrm{COOH}$ and COOD groups in dimeric carboxylic acids. I. The region from 1500 to $500 \mathrm{~cm}^{-1}$. Proc. Roy. Soc. Ser. A 1953, 216, 247-266.

33. Lin-Vien, D.; Colthup, N.B.; Fateley, W.G.; Grasselli, J.G. The Handbook of Infrared and Raman Characteristic Frequencies of Organic Molecules; Jovanovich, H.B., Ed.; Academic Press Inc.: San Diego, CA, USA, 1991; p. 140.

34. Socrates, G. Infrared and Raman Charactheristic Group Frequencies, 3rd ed.; John Wiley and Sons Ltd: New York, NY, USA, 2004.

35. De Dobbelaere, C.; Mullens, J.; Hardy, A.; Van Bael, M.K. Thermal decomposition and spectroscopic investigation of a new aqueous glycolato(-peroxo) Ti(IV) solution-gel precursor. Thermochim. Acta 2011, 520, 121-133. [CrossRef]

36. Sourisseau, C.; Fouassier, M.; Mauricot, R.; Boucher, F.; Evain, M. Structure and bonding in cerium oxysulfide compounds. II-Comparative lattice dynamics calculations on $\mathrm{Ce}_{2} \mathrm{O}_{2} \mathrm{~S}$ and $\mathrm{Ce}_{2.0} \mathrm{O}_{2.5}$ S. J. Raman Spectrosc. 1997, 28, 973-978. [CrossRef]

37. Lu, Y.; Deng, G.; Miao, F.; Li, Z. Metal ion interactions with sugars. The crystal structure and FT-IR study of the NdCl $\mathrm{N}_{3}-\mathrm{ribose}$ complex. Carbohydr. Res. 2003, 338, 2913-2919. [CrossRef] [PubMed]

38. Sohn, J.R.; Chun, E.W.; Pae, Y.I. spectroscopic studies on $\mathrm{ZrO}_{2}$ odified with $\mathrm{MoO}_{3}$ and activity for acid catalysis. Bull. Korean Chem. Soc. 2003, 24, 1785-1792.

39. Jayaraman, A.; Sharma, S.K.; Wang, S.Y.; Shieh, S.R.; Ming, L.C.; Cheong, S.W. Pressure-induced phase transitions in $\left.\mathrm{KDy}_{(\mathrm{MoO}}\right)_{2}$ and $\mathrm{KY}\left(\mathrm{MoO}_{4}\right)_{2}$ : A high-pressure raman study. J. Raman Spectrosc. 1996, 27, 485-490. [CrossRef]

40. Fielicke, A.; Meijer, G.; Von Helden, G. Infrared multiple photon dissociation spectroscopy of transition metal oxide cluster cations. Eur. Phys. J. D 2003, 24, 69-72. [CrossRef]

41. Feng, C.; Aldrich, C.; Eksteen, J.J.; Arrigan, D.W.M. Removal of arsenic from gold processing circuits by use of novel magnetic nanoparticles. Can. Metal. Quart. 2018, 57, 399-404. [CrossRef]

42. Lewandowski, W.; Dasiewicz, B.; Koczon, P.; Skierski, J.; Dobrosz-Teperek, K.; Swislocka, R.; Fuks, L.; Priebe, W.; Mazurek, A.P. Vibrational study of alkaline metal nicotinates, benzoates and salicylates. J. Mol. Struct. 2002, 604, 189-193. [CrossRef]

43. Koczon, P.; Lewandowski, W.; Mazurek, A.P. Vibrational (FT-IR and FT-Raman) and NMR studies on selected metal (Ca, Mn, Zn) complexes with ortho-, meta-, and para-iodobenzoic acids. Vib. Spectrosc. 1999, 20, 143-149. [CrossRef]

44. Kakiuchi, M.; Abe, T.; Nakayama, H. D/H fractionation factor between water vapor and crystal water of copper chloride dihydrate: Statistical mechanical approach based on Raman spectra. Geochem. J. 2001, 35, 285-293. [CrossRef] 
45. Wang, K.; Li, Y.S. Silver doping of polycarbonate films for surface-enhanced Raman scattering. Vib. Spectrosc. 1997, 14, 183-188. [CrossRef]

46. Boerio, F.J.; Hong, P.P.; Clark, P.J.; Okamoto, Y. Surface-enhanced Raman scattering from model acrylic adhesive systems. Langmuir 1990, 6, 721-727. [CrossRef]

47. Kwon, Y.J.; Son, D.H.; Ahn, S.J.; Kim, M.S.; Kim, K. Vibrational spectroscopic investigation of benzoic acid adsorbed on silver. J. Phys. Chem. 1994, 98, 8481-8487. [CrossRef]

48. Galdecka, E.; Galdecki, Z.; Huskowska, E.; Amirkhanov, V.; Legendziewicz, J. Crystal structure and optical properties of Ln(III) octahedral complexes with hexamethylphosphortriamide; [Ln(HMPA) 6 ] $\left(\mathrm{ClO}_{4}\right)_{3}$. J. Alloy. Compd. 1997, 257, 182-190. [CrossRef]

49. De Andrés, A.; Taboada, S.; Martinez, J.L.; Salinas, A.; Hernandez, J.; Saez-Puche, R. Optical phonons in $\mathrm{R}_{2} \mathrm{BaMO}_{5}$ oxides with $\mathrm{M}=\mathrm{Co}, \mathrm{Ni}, \mathrm{Cu}$, and $\mathrm{R}=$ a rare earth. Phys. Rev. B 1993, 47, 14898. [CrossRef]

50. Cho, B.O.; Lao, S.X.; Chang, J.P. Origin and effect of impurity incorporation in plasma-enhanced $\mathrm{ZrO}_{2}$ deposition. J. Appl. Phys. 2003, 93, 9345. [CrossRef]

51. Kostova, I.; Traykova, M. Cerium(III) and neodymium(III) complexes as scavengers of X/XO-derived superoxide radical. Med. Chem. 2006, 2, 463-470. [CrossRef]

52. Kostova, I.; Traykova, M.; Rastogi, V.K. New lanthanide complexes with antioxidant activity. Med. Chem. 2008, 4, 371-378. [CrossRef]

53. Kostova, I.; Rastogi, V.K.; Kiefer, W.; Kostovski, A. New cerium (III) and neodymium (III) complexes as cytotoxic agents. Appl. Organometal. Chem. 2006, 20, 483-493. [CrossRef]

54. Frisch, M.J.; Trucks, G.W.; Schlegel, H.B.; Scuseria, G.E.; Robb, M.A.; Cheeseman, J.R.; Scalmani, G.; Barone, V.; Petersson, G.A.; Nakatsuji, H.; et al. Gaussian 09, Revision A.02; Gaussian Inc.: Wallingford, CT, USA, 2016.

55. Becke, A.D. Density-functional thermochemistry. III. The role of exact exchange. J. Chem. Phys. 1993, 98, 5648-5652. [CrossRef]

56. Lee, C.; Yang, W.; Parr, R.G. Development of the Colle-Salvetti correlation-energy formula into a functional of the electron density. Phys. Rev. B 1988, 37, 785-789. [CrossRef] [PubMed]

57. Vosko, S.H.; Wilk, L.; Nusair, M. Accurate spin-dependent electron liquid correlation energies for local spin density calculations: A critical analysis. Can. J. Phys. 1980, 58, 1200-1211. [CrossRef]

58. Stephens, P.J.; Devlin, F.J.; Chabalowski, C.F.; Frisch, M.J. Ab initio calculation of vibrational absorption and circular dichroism spectra using density functional force fields. J. Phys. Chem. 1994, 98, 11623-11627. [CrossRef]

59. Dunning, T.H., Jr. Gaussian basis sets for use in correlated molecular calculations. I. The atoms boron through neon and hydrogen. J. Chem. Phys. 1989, 90, 1007. [CrossRef]

60. Dunning, T.H., Jr.; Hay, P.J. Gaussian basis sets for molecular calculations. In Modern Theoretical Chemistry; Schaefer, H.F., III, Ed.; Springer: New York, NY, USA, 1977; pp. 1-28.

61. Tirado-Rives, J.; Jorgensen, W.L. Performance of B3LYP density functional methods for a large set of organic molecules. J. Chem. Theory Comput. 2008, 4, 297-306. [CrossRef]

62. Lumpe, H.; Pol, A.; Op den Camp, H.J.M.; Daumann, L.J. Impact of the lanthanide contraction on the activity of a lanthanidedependent methanol dehydrogenase-A kinetic and dft study. Dalton Trans. 2018, 47, 10463-10472. [CrossRef]

63. Mosmann, T. Rapid colorimetric assay for cellular growth and survival: Application to proliferation and cytotoxicity assays. J. Immunol. Methods 1983, 65, 55-63. [CrossRef] 